DOI: https://doi.org/10.24867/15FA08Doderovic

\title{
АРХИТЕКТОНСКИ ПРОЈЕКАТ ЈЕДНОПОРОДИЧНОГ СТАНОВАЊА ПРЕМА ПРИНЦИПИМА ОДРЖИВОГ РАЗВОЈА
}

\section{ARCHITECTURAL PROJECT OF SINGLE-FAMILY HOUSING ACCORDING TO THE PRINCIPLES OF SUSTAINABLE DEVELOPMENT}

\author{
Milena Doderović, Fakultet tehničkih nauka, Novi Sad
}

\section{Област - АРХИТЕКТУРА}

Кратак садржај - Рад садржи приказ истраживачког и пројектантског процеса рада и подељен је на три целине. Прве две целине чине истраживачки део рада који се бави анализом општег појма одрживог развоја, сужавајући га до юегове примене на архитектуру, представљајући изабране изведене примере кроз студије случаја. Трећа целина се односи на пројектантски део рада који настаје као резултат анализе истраживачког дела и подразумева опис програма и концепта, као и техничке иртеже и ЗД приказе.

Кључне речи: Једнопородично становање, одрживи развој, одржива архитектура, обновљиви извори енергије

Abstract - This paper contains a review of researching and designing processes and is divided into three parts. The first two units represent the research parm of the thesis that deals with the analysis of the general concept of sustainable development, narrowing it down to its application to architecture, presenting selected derived examples through case studies. The third unit refers to the design part of the work that arises as a result of the analysis of the research work and includes a description of the program and concept, as well as technical drawings and $3 D$ representations.

Keywords: Single-family Housing, Sustainable Development, Sustainable Architecture, Renewable Energy Sources

\section{1. УВОД}

\section{1. Опис изабране теме}

Овај рад се бави истраживањима из области одрживог развоја и могућностима примене таквог концепта у архитектонским решењима.

Најпре су анализиране теоретске основе одрживости, а затим методе одрживе архитектуре кроз примену обновљивих извора енергије и нових препорука за пројектовање.

Како би се дошло до пројектантског решења везаног за тему, неопходно је било и издвојити одређене примере изведених и пројектованих решења која примењују концепт одрживости.

\section{НАПОМЕНА:}

Овај рад проистекао је из мастер рада чији ментор је била др Ивана Мишкељин, ванр. проф.
Уз помоћ поменутих истраживања, а након одређених закључака, дат је предлог архитектонског решења једнопородичне куће, на коме ће бити примењени неки од претходно анализираних принципа одрживог развоја.

\section{2. Дефинисање појмова}

Одрживи развој је нов начин размишљања о нашој природној околини, и људском деловању на њу, кроз процес измене у раду многих струка где су експлоатација природних ресурса, усмеравање инвестиција и унапређење технолошког развоја, у складу са садашњим, али уз компромис према будућим генерацијама.

Одржива архитектура, као примена концепта одрживог развоја у архитектури, грађевинарству и урбанизму је од великог значаја јер управо ове области, кроз своја решења и својом међусобном повезаношћу деловања, могу значајно да измене и утичу на одређене функције животне средине, односно, оне поседују огроман потенцијал за обликовање одрживог окружења.

\section{3. Циљ}

Суштина је да се деградација животне средине заустави изнад нивоа њене природне способности регенерације, а у архитектури то можемо постићи новим правилима приликом процеса пројектовања и извођења која подразумевају:

-адекватну искоришћеност грађевинског простора; -погодну повезаност са суседством; -једноставну форму; -рационалну потрошњу воде и енергије; -употребу обновљивих извора енергије, -збрињавање отпада; -удобност корисника; -функционалност објекта кроз његово комплетно животно раздобље.

\section{2. ПРИМЕНА ОДРЖИВОГ РАЗВОЈА НА АРХИТЕКТУРУ}

\section{1. Обновљиви извори енергије}

- Енергија соларног зрачења

- пасивно искоришћење адекватном оријентацијом објекта у односу на Сунце.

- активно коришћење енергије из соларних колектора или панела.

- Хидроенергија. 
На свим већим рекама, ова енергија се већ користи, али мање реке нуде могућност за изградњу мањих електрана.

Када се помиње вода, неопходно је приметити да се велики проценат техничке воде у домаћинствима може заменити кишницом.

- Геотермална енергија

Разним пумпама се може искористити топлота земљине унутрашњости за системе загревања и хлађења објеката.

- Енергија ветра

- Остали алтернативни извори енергије.

\section{2. Типови одрживих кућа}

Идентификовано је пуно различитих термина за опис кућа пројектованих према принципима одрживости: нискоенергетска кућа, пасивна кућа, нулта кућа, соларна кућа, еко кућа... свака од ових кућа има посебне захвате и концепте пројектовања, а оно што им је свима заједничко је да се тежи смањењу потрошње енергија, а самим тим смањењу потрошње необновљивих ресурса и очувању животне средине путем коришћења обновљивих извора енергије који не загађују околину, тј. испуштају мало или нимало угљен-диоксида.

\section{3. Савети и алати за пројектовање према принципима одрживости}

Адекватна оријантација објекта у односу на Сунце и ветар може знатно да смањи потребу за потрошњом произведене енергије за загревање односно хлађење просторија.

Једноставни облици су повољнији јер сложене форме у конструкцији компликују постављање изолације.

Затим се у овом одељку могу пронаћи дијаграми и објашњења о препорукама оптималног распореда просторија као и употреби одређених структура попут атријума и стаклених башти.

Конструкција објекта и материјали се не разликују много од конвенционалне градње, али постоје препоруке за предност одређених у зависности од неких других фактора попут локацијских услова.

Изведби термоизолације и доброј и квалитетној столарији се поклања посебна пажња приликом одабира и изведбе.

Предлажу се идеје на који би се начин могле искористити погодности тла на локацји.

\section{4. Студија случаја}

Назив пројекта: Slip House

Локација: Брикстон, Лондон, Велика Британија

Аутор: Carl Turner Architects

Површина: $200 \mathrm{M}^{2}$

Година: 2012.

Ова кућа представља прототип учења о одрживом дизајну као и начинима изградње приуштивих домова. Скуп технологија које ову кућу чине енергетски ефикасном су:

-соларна топлотна пумпа за термички комфор; -фотонапонске ћелије које стварају електричну енергију;

-механичка вентилација са повратом топлоте; -непропусна овојница са дебелим слојевима изолације;

-млечни, прозрачни стаклени зидови за пропуштање Сунчевих зрака у ентеријер;

-систем прикупљања кишнице, што смањује потрошњу техничке воде;

-зелена тераса од дивљих цветова

\section{3. ИДЕЈНИ ПРОЈЕКАТ ЈЕДНОПОРОДИЧНЕ КУЋЕ}

\section{1. Програм и концепт}

Циљ је осмислити животни амбијент за четворочлану породицу, који испуњава њихове основне просторне потребе, али и примену препорука и савета одрживих принципа приликом пројектовања уз употребу одређених технологија које користе обновљиве изворе енергије.

\section{2. Примена принципа одрживости на пројекат}

Препоручена оријентација објекта у односу на Сунце и на ветар је решена тако да су мали отвори постављени на северу, а велики отвори на јужној фасади. Тиме је са пројектантске стране акумулација топлоте обазбеђена. Садњом високе вегетације биће ублажени јаки продори ветрова са северне стране.

На основи приземља пројектованог објекта (слика 1) приказан је начин на који је испоштована просторна организација. Постављене су просторије у којима је дужи боравак на јужној страни, а све техничке и помоћне просторије које подразумевају краћи боравак корисника позициониране су на северу.

На основи спрата (слика 2) приказан је помоћни радни простор, чија је главна идеја флексибилност. Могу га користити становници куће, а могу га и издавати другим лицима јер је предвиђен посебан улаз.

Конструктивни материјали су у складу са принципима одрживе градње, спољашњи носиви зидови су од Ytong блокова дебљине 30цм. Имајући у виду карактеристике поднебља у ком се смењују четири годишња доба, и велике су температурне разлике, одлучено је да се зид обезбеди са 12цм топлотне изолације Ytong мултипором.

Под приземља је осмишљен као под на тлу са подним грејањем. За све прозоре и спољна врата на кући

иза брани су црни рамови комбинација дрвоалуминијум, квалитетно израђени од профила без топлотног моста. Трослојна стакла са коморама између које су испуњене термоизолујућим гасом аргоном. Сваки прозор, без обзира на своју величину и позицију има засенчења или топлотни застор.

У пројекту је покушано кроз просторну организацију, позицију отвора, избор материјала и боја, што боље пасивно искористити и светлост и топлоту Сунца, што се може уочити на јужној фасади (слика 3) али додатак пројекту биће и активан принцип коришћења соларне енергије кроз систем соларне електране (соларне панеле).

Соларни панели смештени су на крову објекта.

У оквиру радног пројекта кишница ће се користити помоћу два одвојена система: 
Главни - за радње попут чишћења, прања рубља, прања аутомобила-техничка вода.

Додатни - за спрат, како би тај простор био независан од остатка.

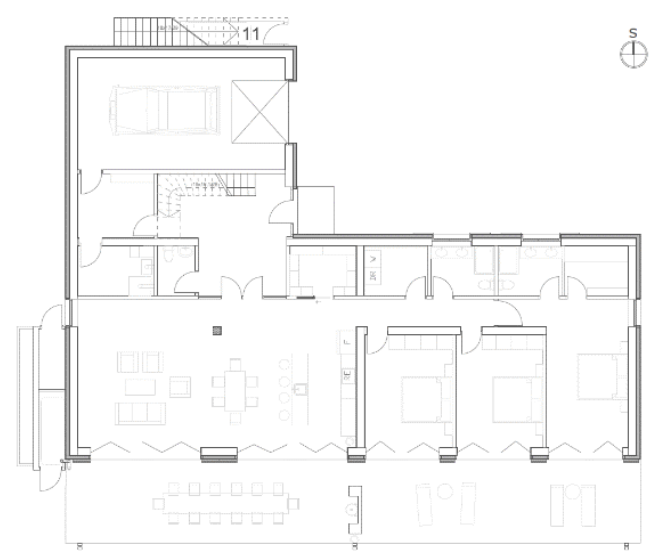

Слика 1. Основа приземља

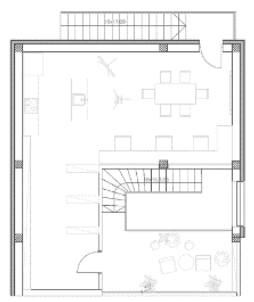

Слика 2. Основа спрата

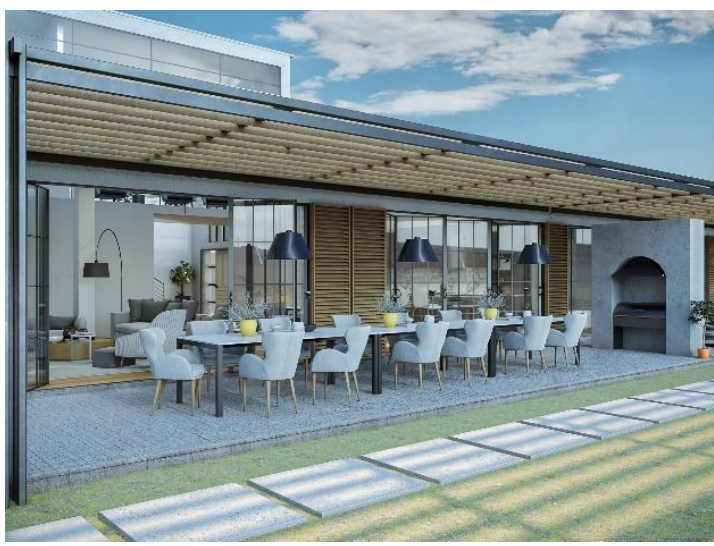

Слика 3. Приказ дела јужне фасаде објекта

\section{4. ЗАКЉУЧАК}

Када се пореде класична и одржива градња, висока стартна цена одрживе је често довољан разлог да се од исте одустане. Заиста јесте неопходно уложити у јаку изолацију и квалитетне прозоре и врата, међутим, сви остали материјали су исти као и код класичне градње, само је потребно зауставити се, осмотрити и осетити свет око себе, покушати освестити оно што су људи давно у историји радили, а то је на који начин искористити благодети природе, и онда приступити пројектовању.

Време би показало да је одржив начин градње дугорочно исплатив, а када се такав састав допуни одређеним технологијама које користе природне ресурсе, једна породична кућа постаје и одржива структура минимално штетна по природно окружење без смањене функционалности по кориснике, а то је оно што је главни циљ.

\section{5. ЛИТЕРАТУРА}

[1] Konstatinović Dragana. Docent. Programske osnove održive arhitekture - slučaj savremenih poslovnih zgrada. (elaborate, Univerzitet u Novom Sadu, FTN Departman za arhitekturu i urbanizam, 2009.)

[2] Stevović i Vasilski. Održiva arhitektura. Beograd: Zadužbina Andrejević. 2010.

[3] https://www.dezeen.com/2012/09/27/slip-house-bycarl-turner-architects/ (pristupljeno u junu 2020.)

\section{Кратка биографија:}

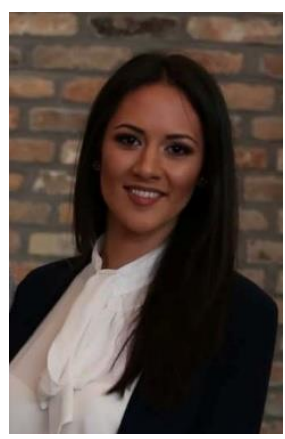

Милена Додеровић рођена је у Београду 1992. год. Основне студије на Факултету техничких наука у Новом Саду из области Архитектура, завршила је 2018. год. Мастер рад брани 2021.год. из области Архитектонско пројектовање, а из студијске групе Дизајн ентеријера. 